\title{
Штучна вентиляція легенів у пацієнтів з морбідним ожирінням під час лапаротомних баріатричних операцій
}

\author{
А. П. Мазур, О. В. Винниченко, В. М. Шевченко, О. В. Ашаренков
}

Національний інститут хірургії і трансплантології імені О. О. Шалімова НАМН України, м. Київ

\section{Artificial pulmonary ventilation in patients, suffering morbid obesity, during laparotomic bariatric operations}

\author{
A. P. Mazur, O. V. Vynnychenko, V. M. Shevchenko, O. V. Asharenkov \\ Shalimov National Institute of Surgery and Transplantology, Kyiv
}

\section{Реферат}

Мета. Порівняти вплив на систему дихання штучної вентиляції легенів (ШВЛ) у режимі примусової вентиляції за об’ємом і за тиском у пацієнтів з МО.

Матеріали і методи. Проведено дослідження щодо 90 пацієнтів, прооперованих з приводу МО. Індекс маси тіла (IMT)

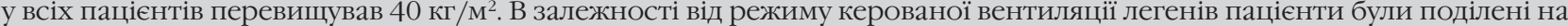
дві групи: 1 -ша група (n = 46) - ШВЛ з контролем за об'ємом (VCV), 2-га група $(\mathrm{n}=44)$ - ШВЛ $з$ контролем за тиском (PCV). В інтраопераційному періоді вимірювали рівень газів артеріальної крові і фіксували показники механіки дихання.

Результати. У 1 -й групі (VCV) середній дихальний об'єм (ДО) становив $(11,5 \pm 4,3)$ мл/кг з розрахунку на ідеальну масу тіла, у 2-й групі (PCV) - (9,4 $\pm 3,2)$ мл/кг. В кінці операції рівень парціального напруження кисню в артеріальній крові $\left(\mathrm{P}_{2} \mathrm{O}_{2}\right)$ був достовірно вищим у групі PCV $(14,8 \pm 4,0)$ кПа $(110,8 \pm 29,7$ мм рт. ст.) порівняно 3 групою VCV $-(12,5 \pm 1,3)$ кПа $(93,5 \pm 9,9$ мм рт. ст.).

Висновки. Проведене дослідження виявило, що особливої різниці у пацієнтів з МО між ШВЛ з VCV і ШВЛ з PCV немає.

ключові слова: штучна вентиляція легенів, керована за об’ємом; штучна вентиляція легенів, керована за тиском; механіка дихання; морбідне ожиріння.

\section{Abstract}

Objective. To compare the impact of artificial pulmonary ventilation (APV) in regime of the forced ventilation for volume and pressure on respiratory system of patients, suffering MO.

Materials and methods. Investigation of 90 patients, operated for MO, was conducted. Body mass index (BMI) of all the patients have exceeded $40 \mathrm{~kg} / \mathrm{m}^{2}$. Depending on regime of guided pulmonary ventilation the patients were divided on two groups: Group I $(n=46)$ - APV with control for volume (VCV), Group II $(n=44)$ - APV with control for pressure (PCV). Intraoperatively the arterial blood gases level was measured and the respiratory mechanics indices registered.

Results. In Group I (VCV) the average respiratory volume have constituted (11.5 \pm 4.3$) \mathrm{ml} / \mathrm{kg}$, calculated for ideal body mass, and in Group II PCV - $(9.4 \pm 3.2) \mathrm{ml} / \mathrm{kg}$. At the end of operation the level of the oxygen partial pressure in arterial blood $\left(\mathrm{P}_{\mathrm{a}} \mathrm{O}_{2}\right)$ was trustworthily higher in a PCV group $(14.8 \pm 4.0) \mathrm{kPa}(110.8 \pm 29.7 \mathrm{~mm} \mathrm{Hg})$, comparing with a VCV group $-(12.5 \pm 1.3) \mathrm{kPa}$ (93.5 $\pm 9.9 \mathrm{~mm} \mathrm{Hg})$.

Conclusion. The investigation conducted have revealed, that essential difference in patients with MO between APV with VCV and APV with PCV in the patients is absent.

Keywords: artificial pulmonary ventilation, guided for volume; artificial pulmonary ventilation, guided for pressure; respiratory mechanics; morbid obesity.

Підтримання адекватної оксигенації і уникнення пошкодження легенів під час проведення інтраопераційної ШВЛ залишається серйозною проблемою у хворих з МО. Багато точиться дискусій відносно режимів вентиляції [1], немає чіткості і в питаннях сприятливого положення пацієнта, оптимального рівня позитивного тиску в кінці видоху (ПТКВ) під час здійснення преоксигенації.

На даний момент існує думка, що різниці між ШВЛ з контролем за тиском і ШВЛ з контролем за об'ємом немає - обидва режими в однаковій мірі впливають на газообмін, тиск у дихальних шляхах і середній артеріальний тиск $[2,3]$.

R. Bell i S. Rosenbaum [4] вважають, що режим вентиляції легенів за тиском дає змогу обмежувати його рівень у дихальних шляхах і тому безпечніший для хворих з МО. Хоча у пацієнтів з вентиляцією легенів, керованою за тиском, рівень $\mathrm{P}_{\mathrm{a}} \mathrm{O}_{2}$ в інтраопераційному періоді вищий, серцевий викид знижується, це не впливає на рівень $\mathrm{P}_{\mathrm{a}} \mathrm{O}_{2}$ і об'єм мертвого простору [5]. Не слід забувати, що помірна гіперкапнія через викликану нею гіперемію покращує тканинну оксигенацію, позитивно впливаючи на репаративні процеси та результати баріатричних операцій у пацієнтів з МО [6, 7]. Оскільки причиною більшості післяопераційних ускладнень $є$ проблеми 3 анастомозами, у кожного пацієнта слід робити вибір досягати нормального дихання чи дбати про покращення мікроциркуляції в ділянці операції.

\section{Матеріали і методи дослідженн}

Дослідження проведено щодо 90 пацієнтів, прооперованих з приводу МО. ІМТ у всіх пацієнтів перевищував 40 кг $/ \mathrm{M}^{2}$. Перед операцією всім хворим проводили комплексне обстеження для виявлення супутніх захворювань та метаболічних зрушень (лабораторні тести, непряму спірометрію, ехокардіографію, рентгенографію органів грудної порожнини), визначали масу тіла, IMT, іде- 


\begin{tabular}{|c|c|c|c|}
\hline \multirow{2}{*}{ Показник } & \multicolumn{2}{|c|}{ Група пацієнтів } & \multirow{2}{*}{$\mathrm{p}$} \\
\hline & 1-ша & 2-га & \\
\hline Вік, роки $(\bar{x} \pm m)$ & $44,0 \pm 9,0$ & $44,5 \pm 8,7$ & 0,812 \\
\hline Стать, ч/ж & $23 / 23$ & $16 / 28$ & 0,192 \\
\hline IMT, $\mathrm{kr} / \mathrm{M}^{2}(\overline{\mathrm{x}} \pm \mathrm{m})$ & $48,8 \pm 7,0$ & $51,8 \pm 10,4$ & 0,117 \\
\hline ІдМТ, кг $(\bar{x} \pm m)$ & $58,7 \pm 3,2$ & $64,2 \pm 4,4$ & 0,115 \\
\hline $\begin{array}{l}\text { Цукровий діабет, } \\
\text { абс.(\%) }\end{array}$ & $16(34,8)$ & $14(31,8)$ & 0,766 \\
\hline $\begin{array}{l}\text { Артеріальна } \\
\text { гіпертензія, абс.(\%) }\end{array}$ & $40(87,0)$ & $39(88,6)$ & 0,808 \\
\hline $\begin{array}{l}\text { Синдром } \\
\text { обструктивного } \\
\text { апное, абс.(\%) }\end{array}$ & $7(15,2)$ & $7(15,9)$ & 0,928 \\
\hline
\end{tabular}

альну масу тіла (ІдМТ), яку обчислювали за калькулятоpoм Metropolitan life. У пацієнтів були виконані відкриті операції: біліопанкреатичне шунтування з виключенням дванадцятипалої кишки за Hess-Marceuo та рукавну резекцію шлунку.

У залежності від режиму керованої вентиляції легенів пацієнти були поділені на дві групи: 1-ша група (n = 46) - ШВЛ з VCV, 2-га група $(\mathrm{n}=44)$ - ШВЛ з PCV. Загальна характеристика пацієнтів обох груп подана в табл. 1 .

В обох групах хворих простежено зміни параметрів ШВЛ та газів артеріальної крові на етапах відкритого хірургічного лікування хворих з МО (табл. 2). Всім хворим була проведена загальна анестезія з ШВЛ з використанням ПТКВ апаратами Primus фірми Dräger. Під час операції фіксували такі показники: $\mathrm{P}_{\text {aw }}$ (опір в дихальних шляхах), Рір (максимальний тиск на вдосі), $\mathrm{P}_{\text {plateu }}$ (постійний тиск у дихальних шляхах), ДО, ЧД (частоту дихання), еtCO (концентрацію вуглекислоти на видосі), ПТКВ, $\mathrm{P}_{\mathrm{a}} \mathrm{O}_{2}$ i $\mathrm{P}_{\mathrm{a}} \mathrm{CO}_{2}$ (парціальне напруження вуглекислого газу в артеріальній крові).

\section{Результати}

Середній ДО у 1-й групі (ШВЛ з VCV) становив (11,5 \pm 4,3) мл/кг з розрахунку на ІдМТ, у 2-й групі (PCV) - (9,4 $\pm 3,2)$ мл/кг. Хоча за даними літератури ДО повинен бути 5 - 8 мл/кг з розрахунку на ІдМТ для запобігання перерозтягнення легенів і волюмотравми [8], у пацієнтів 3 надлишковою вагою, особливо з суперожирінням, можна використовувати ДО 12 мл/кг [9]. Не слід забувати, що застосування високого ДО може погіршувати функціонування дихальної системи [10].

Рівень ПТКВ в обох групах був нижчий рекомендованого, що дозволило зберегти нормальну функціональну ємність легенів і не допустити розвитку гіпоксії.

Хоча у пацієнтів, яким застосовували режим ШВЛ з $\mathrm{PCV}$, рівень $\mathrm{P}_{\mathrm{a}} \mathrm{CO}_{2}$ був вищий, це не впливало на рівень $\mathrm{P}_{\mathrm{a}} \mathrm{O}_{2}$. Помірна гіперкапнія $є$ фізіологічною для хворих 3 МО. В кінці операції $\mathrm{P}_{\mathrm{a}} \mathrm{O}_{2}$ був достовірно вищим у 2-й групі (ШВЛ з РCV) -(14,8 \pm 4,0) кПа $(110,8 \pm 29,7$ мм рт. ст.), ніж у 1-й групі (ШВЛ з VCV) - $(12,5 \pm 1,3)$ кПа $(93,5$ $\pm 9,9$ мм рт. ст.).

\section{Обговорення}

Хворі з МО потребують індивідуального підходу для вибору режимів ШВЛ з урахуванням початкового стану пацієнта (наявність супутньої респіраторної та серце-

\begin{tabular}{|c|c|c|c|}
\hline \multirow[t]{3}{*}{ Таблиця 2.} & \multicolumn{3}{|c|}{$\begin{array}{l}\text { Параметри ШВЛ з VCV та ШВЛ з PCV } \\
\text { і газів артеріальної крові на етапах } \\
\text { лапаротомних операцій у хворих з МО } \\
(\bar{x} \pm m)\end{array}$} \\
\hline & \multicolumn{2}{|c|}{ Групи пацієнтів } & \multirow{2}{*}{$\mathrm{p}$} \\
\hline & 1-ша & 2-га & \\
\hline ДО, мл & $614,6 \pm 66,0$ & $603,4 \pm 66,8$ & 0,428 \\
\hline чД, 1/хв & $14,5 \pm 2,4$ & $14,3 \pm 2,3$ & 0,687 \\
\hline \multicolumn{4}{|l|}{ Рip, гПа } \\
\hline 1 & $24,8 \pm 1,2$ & $21,9 \pm 2,6$ & 0,009 \\
\hline 2 & $22,5 \pm 1,8$ & $19,6 \pm 2,4$ & 0,015 \\
\hline 3 & $24,2 \pm 1,5$ & $22,9 \pm 2,8$ & 0,263 \\
\hline \multicolumn{4}{|l|}{$\mathrm{P}_{\text {plateu }}$ гПа } \\
\hline 1 & $24,3 \pm 1,4$ & $20,9 \pm 3,1$ & 0,010 \\
\hline 2 & $22,2 \pm 1,7$ & $18,7 \pm 2,7$ & 0,008 \\
\hline 3 & $23,8 \pm 1,3$ & $21,3 \pm 2,8$ & 0,034 \\
\hline ПТКВ, гПа & $2,28 \pm 2,80$ & $3,34 \pm 2,75$ & 0,074 \\
\hline \multicolumn{4}{|l|}{$C_{\text {pat }}$, мл/гПа } \\
\hline 1 & $30,6 \pm 2,4$ & $32,0 \pm 4,6$ & 0,448 \\
\hline 2 & $34,9 \pm 1,7$ & $34,8 \pm 5,1$ & 0,945 \\
\hline 3 & $29,4 \pm 1,6$ & $29,4 \pm 3,3$ & 0,983 \\
\hline \multicolumn{4}{|l|}{$\mathrm{P}_{\mathrm{a}} \mathrm{O}_{2}, \mathrm{k} П \mathrm{a}$} \\
\hline 1 & $15,5 \pm 6,5$ & $17,1 \pm 7,3$ & 0,667 \\
\hline 2 & $16,9 \pm 6,7$ & $22,0 \pm 9,0$ & 0,228 \\
\hline 3 & $12,5 \pm 1,3$ & $14,8 \pm 4,0$ & 0,0001 \\
\hline \multicolumn{4}{|l|}{$\mathrm{P}_{\mathrm{a}} \mathrm{CO}_{2}, \mathrm{k} \Pi \mathrm{a}$} \\
\hline 1 & $5,0 \pm 0,5$ & $5,2 \pm 0,8$ & 0,667 \\
\hline 2 & $4,7 \pm 0,3$ & $5,4 \pm 0,5$ & 0,008 \\
\hline 3 & $5,6 \pm 0,5$ & $5,7 \pm 1,0$ & 0,915 \\
\hline Примітка. & \multicolumn{3}{|c|}{$\begin{array}{l}\text { Етапи оперативного втручання: } \\
1 \text { - до лапаротомії, } 2 \text { - після лапаротомії, } \\
3 \text { - після зашивання рани; } C_{\text {pat }} \text { - статичний } \\
\text { комплайнс. }\end{array}$} \\
\hline
\end{tabular}

во-судинної патологіi), характеру оперативного втручання. Під час відкритих операцій необхідна оперативність у зміні параметрів і режимів ШВЛ для забезпечення достатньої оксигенації, профілактики перерозтягування легенів та волюмотравми.

До моменту лапаротомії краще використовувати режим ШВЛ з PCV. Після виконання лапаротомії ДО збільшуємо, тому на даному етапі операції краще застосовувати режим ШВЛ з VCV, щоб уникнути волюмотравми. Одначе даний режим має недоліки - підвищення тиску в дихальних шляхах і збільшення шунтування в легенях, через що на етапі зашивання черевної порожнини у хворих $з$ високими значеннями IMT (більше $50 \mathrm{\kappa г} / \mathrm{m}^{2}$ ) режим ШВЛ з VCV варто застосовувати обережно.

Особливої різниці між ШВЛ з VCV і ШВЛ з PCV при виконанні лапаротомних операцій у пацієнтів з МО в плані порушень параметрів легеневої вентиляції і даних газообміну немає.

\section{Висновки}

1. Проведене дослідження не виявило особливої різниці між ШВЛ з VCV і ШВЛ з РCV у пацієнтів з МО.

2. Для оптимізації показників механіки дихання і газообміну на різних етапах лапаротомних операцій (після індукції анестезії і інтубації, лапаротомії і зашивання лапаротомної рани) потрібно змінювати режими ШВЛ. 


\section{References}

1. Bamgbade OA, Rutter TW, Nafiu OO, et al. Postoperative complications in obese and nonobese patients. World J Surg.2007;31:556-60; discussion 561. PMID: 16957821. doi: 10,1007/s00268-006-0305-0.

2. Prella M, Feihl F, Domenighetti G. Effects of short-term pressure-controlled ventilation on gas exchange, airway pressures, and gas distribution in patients with acute lung injury ARDS: comparison with volumecontrolled ventilation. Chest. 2002;122:1382-8. PMID: 12377869.

3. Esteban A, Alía I, Gordo F, de Pablo R, Suarez J, González G, Blanco J. Prospective randomized trial comparing pressure-controlled ventilation in ARDS. For the Spanish Lung Failure Collaborative Group. Chest. 2000;117(6):1690-6. PMID: 10858404.

4. Bell RL, Rosenbaum SH. Postoperative considerations for patients with obesity and sleep apnea. Anesth Clin North America. 2005;23(3):493500. PMID: 6005826. doi: 10,1016/j.atc.2005.03.007.

5. Nyarwaya JB, Mazoit JX, Samii K. Are pulse oximetry and end-tidal carbon dioxide tension monitoring reliable during laparoscopic surgery? Anaesthesia. 1994;49:775-8. PMID: 7978132.
6. Fleischmann E, Herbst F, Kugener A, Kabon B, Niedermayr M, Sessler DI, et al. Mild hypercapnia increases subcutaneous and colonic oxygen tension in patients given $80 \%$ inspired oxygen during abdominal surgery. Anesthesiology. 2006;104:944-9. PMID: 16645445.

7. Hager H, Reddy D, Mandadi G, Pulley D, Eagon JC, Sessler DI, et al. Hypercapnia improves tissue oxygenation in morbidly obese surgical patients. Anesth Analg. 2006;103(3):677-81. doi: 10.1213/01. ane.0000229715.71464.90.

8. El-Dawlatly AA, Al-Dohayan A, Abdel-Meguid ME, El-Bakry A, Manaa EM. The effects of pneumoperineum on respiratory mechanics during general anesthesia for bariatric surgery. Obes Surg. 2004;14:212 5. PMID: 15018750. doi: 10.1381/096089204322857582.

9. Kassil VL, Leskin GS, Vyizhigina MA. Respiratornaya podderzhka: rukovodstvo po iskusstvennoy i vspomogatelnoy ventilyatsii v anesteziologii i intensivnoy terapii. M.:Med. literatura,1997.-174 s. [Russian].

10. Adams JP, Murphy JP. Obesity in anaesthesia and intensive care. Br J Anaesth. 2000;108:85-91. PMID: 10927998. 